\title{
Petrotoga olearia sp. nov. and Petrotoga sibirica sp. nov., two thermophilic bacteria isolated from a continental petroleum reservoir in Western Siberia
}

\footnotetext{
${ }^{1}$ UMR 6539, Centre Nationa de la Recherche Scientifique and Université de Bretagne Occidentale, Institut Universitaire Européen de la Mer, Place Nicolas Copernic, 29280 Plouzané, France

2 Institute of Microbiology, Russian Academy of Sciences, Prospect 60-letiya Oktyabrya 7/2,

117811 Moscow, Russia

${ }^{3}$ DSMZ - German Collection of Microorganisms and Cell Cultures, Mascheroder Weg $1 b$,

38124 Braunschweig, Germany

${ }^{4}$ Laboratoire IRD de Microbiologie des Anaérobies, Université de Provence, CESB-ESIL, case 925,163 avenue de Luminy, 13288 Marseille cedex 9 , France
}

\author{
S. L'Haridon, ${ }^{1}$ M. L. Miroshnichenko, ${ }^{2}$ H. Hippe, ${ }^{3}$ M.-L. Fardeau, ${ }^{4}$ \\ E. A. Bonch-Osmolovskaya, ${ }^{2}$ E. Stackebrandt ${ }^{3}$ and C. Jeanthon ${ }^{1}$
}

\begin{abstract}
Author for correspondence: C. Jeanthon. Tel: +33298 498 751. Fax: +33298498705. e-mail: Christian.Jeanthon@univ-brest.fr
\end{abstract}

\begin{abstract}
Strictly anaerobic, thermophilic bacteria (strains SL24', SL25', SL27, SL29 and SL32) were isolated from a deep, continental oil reservoir in Western Siberia (Russia). These motile, rod-shaped organisms were surrounded by a sheath-like structure, a feature characteristic of the Thermotogales. On the basis of partial $16 S$ rDNA sequences (500 nucleotides), strains SL25', SL27, SL29 and SL32 were identical. Therefore, only strains $S L 24^{\top}$ and $S L 25^{\top}$ were studied in detail. The optimum temperature for growth of both strains was $55^{\circ} \mathrm{C}$. Their optimum pH for growth was 7.5 and their optimum $\mathrm{NaCl}$ concentration was between 20 and $30 \mathrm{~g} \mathrm{I}^{-1}$. The novel isolates reduced elemental sulfur and cystine, but not thiosulfate or sulfate, to hydrogen sulfide. The $G+C$ contents of the genomic DNA of strains SL24 ${ }^{\top}$ and $S{ }^{2} 5^{\top}$ were respectively 35 and $33 \mathrm{~mol} \%$. Phylogenetically, both strains are most closely related to Petrotoga miotherma, there being 98.9-99.4\% similarity between their $16 \mathrm{~S}$ rDNA sequences.

Phenotypic properties and DNA-DNA hybridization experiments indicate that the strains belong to two novel species, for which the names Petrotoga olearia

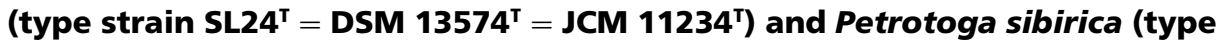
strain $\mathrm{SL25}^{\top}=$ DSM $^{13575^{\top}}=\mathrm{JCM}^{\mathrm{T}} 11235^{\top}$ ) are proposed.
\end{abstract}

Keywords: oilfield, thermophiles, Thermotogales, Petrotoga sibirica, Petrotoga olearia

\section{INTRODUCTION}

Members of the family Thermotogaceae (order Thermotogales) belong to two physiological groups: extreme thermophiles that grow at temperatures above $70{ }^{\circ} \mathrm{C}$ and moderate thermophiles that grow at lower temperatures. The extreme thermophiles encompass the genera Fervidobacterium (Patel et al., 1985), Thermotoga (Huber et al., 1986) and Thermosipho (Huber et al., 1989; Ravot et al., 1996a). Except in the case of Fervidobacterium, which is restricted to continental springs (Patel et al., 1985; Andrews \& Patel, 1996;

Published online ahead of print on 1 March 2002 as DOI 10.1099/ ijs.0.02153-0.

The GenBank accession numbers for the 16S rRNA gene sequences of Petrotoga olearia SL24 ${ }^{\top}$ and Petrotoga sibirica SL25 ${ }^{\top}$ are AJ311702 and AJ311703.
Koch et al., 1997), members of these genera have been isolated and detected in diverse high-temperature environments (Huber et al., 1986, 1989, 1990; Jannasch et al., 1988; Windberger et al., 1989; Stetter et al., 1993; Jeanthon et al., 1995; Ravot et al., 1995; Andrews \& Patel, 1996; Grassia et al., 1996; Antoine et al., 1997; Fardeau et al., 1997; Takahata et al., 2000; Takai \& Horikoshi, 2000). Moderately thermophilic members of the Thermotogales consist of the genera Geotoga and Petrotoga (Davey et al., 1993) and Marinitoga (Wery et al., 2001). The recently discovered genus Marinitoga is, as far as is known, limited to deep-sea hydrothermal vents. Up to now, species of the genera Geotoga and Petrotoga have been retrieved only from deep oil reservoirs. The genus Petrotoga contains two described species, Petrotoga miotherma (Davey et al., 1993) and Petrotoga mobilis (Lien et al., 1998), isolated from petroleum reservoirs from Oklahoma and Texas and from the North Sea, respectively. 
Additional strains closely related to both species were isolated from sulfur-rich reservoirs in California (Orphan et al., 2000).

Recent microbiological studies performed on oil/ water mixtures from different high-temperature strata of the Samotlor oilfields (Western Siberia) have identified phylogenetically diverse thermophilic organisms (Slobodkin et al., 1999; Jeanthon et al., 2000). Among them, novel species of the genera Thermococcus, Thermosipho and Geobacillus have been isolated and characterized (L'Haridon et al., 2001; Miroshnichenko et al., 2001; Nazina et al., 2001). In this paper, we describe the isolation of two novel species of the genus Petrotoga from oilfield waters. Although they are phylogenetically closely related to $P$. miotherma, the two strains (SL24 ${ }^{\mathrm{T}}$ and SL25 ${ }^{\mathrm{T}}$ ) exhibit phenotypic and genetic characteristics consistent with their placement in two novel species of the genus Petrotoga.

\section{METHODS}

Source of organisms. The novel strains were isolated from oil/water mixtures taken directly from production wellheads of a deep, continental petroleum reservoir in Western Siberia (Russia). P. miotherma strain 42-6 $6^{\mathrm{T}}$ (= ATCC $51224^{\mathrm{T}}$ ) was obtained from the ATCC (Manassas, VA, USA).

Enrichment, isolation and growth conditions. Enrichments were performed anaerobically in Hungate tubes containing $10 \mathrm{ml}$ medium, according to Balch \& Wolfe (1976). The enrichment medium consisted of the following $\left(1^{-1}\right.$ distilled water): $20 \mathrm{~g} \mathrm{NaCl}, 0.33 \mathrm{~g} \mathrm{NH}_{4} \mathrm{Cl}, 0.33 \mathrm{~g} \mathrm{KH}_{2} \mathrm{PO}_{4}, 0.33 \mathrm{~g}$ $\mathrm{MgCl}_{2} .6 \mathrm{H}_{2} \mathrm{O}, 0.33 \mathrm{~g} \mathrm{CaCl} \cdot 2 \mathrm{H}_{2} \mathrm{O}, 1 \mathrm{~g} \mathrm{NaHCO}_{3}, 1 \cdot 5 \mathrm{~g}$ peptone, $1.5 \mathrm{~g}$ tryptone, $1.5 \mathrm{~g}$ yeast extract, $0.5 \mathrm{~g}$ $\mathrm{Na}_{2} \mathrm{~S} .9 \mathrm{H}_{2} \mathrm{O}, 1 \mathrm{ml}$ trace-element solution (Kevbrin \& Zavarzin, 1992) and $2 \mathrm{ml}$ vitamin solution (Wolin et al., 1963), and had a $\mathrm{pH}$ at room temperature of 6.8-7. It was inoculated with $1 \mathrm{ml}$ of the oil/water sample, pressurized with $\mathrm{N}_{2}$ $(100 \% ; 100 \mathrm{kPa})$ and incubated without shaking at $58^{\circ} \mathrm{C}$. The medium used for growth, isolation and routine cultivation of the novel strains contained the following $\left(1^{-1}\right.$ distilled water): $25 \mathrm{~g} \mathrm{NaCl}, 0 \cdot 5 \mathrm{~g} \mathrm{MgCl}_{2} \cdot 6 \mathrm{H}_{2} \mathrm{O}, 3 \cdot 4 \mathrm{~g}$ PIPES, $0.2 \mathrm{~g} \mathrm{KCl}, 1 \mathrm{~g} \mathrm{NH}{ }_{4} \mathrm{Cl}, 0.1 \mathrm{~g} \mathrm{CaCl}_{2} .2 \mathrm{H}_{2} \mathrm{O}, 0 \cdot 35 \mathrm{~g} \mathrm{~K}_{2} \mathrm{HPO}_{4}$, $0.35 \mathrm{~g} \mathrm{KH}_{2} \mathrm{PO}_{4}, 1.5 \mathrm{~g}$ peptone, $1.5 \mathrm{~g}$ tryptone, $1.5 \mathrm{~g}$ yeast extract and $1 \mathrm{mg}$ resazurin. The $\mathrm{pH}$ was adjusted to $7 \mathrm{using}$ $5 \mathrm{M} \mathrm{HCl}$ before autoclaving. Prior to inoculation, maltose and $\mathrm{Na}_{2} \mathrm{~S} .9 \mathrm{H}_{2} \mathrm{O}$ were injected from sterile, anaerobic stock solutions to obtain respective final concentrations of $0 \cdot 2 \%$ $(\mathrm{w} / \mathrm{v})$ and $0 \cdot 1 \%$. Single colonies were obtained and purified by streaking on the same medium that was solidified with $1 \%(\mathrm{w} / \mathrm{v})$ Phytagel (a gellan gum from Sigma). Plates were incubated in anaerobic jars at $55^{\circ} \mathrm{C}$ under $\mathrm{N}_{2} / \mathrm{CO}_{2}(80: 20$, $100 \mathrm{kPa}$ ). Stock cultures of isolates SL24 ${ }^{\mathrm{T}}$ and SL25 $5^{\mathrm{T}}$ were stored in culture medium at $4{ }^{\circ} \mathrm{C}$. For long-term storage, pure cultures were stored at $-80{ }^{\circ} \mathrm{C}$ in the same medium containing $10 \%(\mathrm{w} / \mathrm{v})$ DMSO.

Determination of growth parameters. Growth was monitored by measuring the increase in the $\mathrm{OD}_{540}$ with a Spectronic 401 spectrophotometer (Bioblock). All growth experiments were performed in triplicate. The $\mathrm{pH}$ range for growth was determined in culture medium with various buffers, each at a concentration of $10 \mathrm{mM}$ (MES for
pH 5.0-6.0; PIPES for $\mathrm{pH} 6.5$ and 7.0; HEPES for $\mathrm{pH} 7 \cdot 5$; Tris for $\mathrm{pH} 8,8.5$ and 9). Appropriate amounts of $1 \mathrm{M}$ $\mathrm{Na}_{2} \mathrm{CO}_{3}$ were added to adjust the $\mathrm{pH}$ of the medium to $9 \cdot 0-10$. To determine the optimum $\mathrm{NaCl}$ range for growth, the $\mathrm{NaCl}$ concentrations were varied while concentrations of the other inorganic components were maintained. The effects of different $\mathrm{pH}$ values and concentrations of $\mathrm{NaCl}$ were determined at $55^{\circ} \mathrm{C}$.

Substrate-utilization tests. Ability to grow lithoautotrophically was tested in routine medium from which yeast extract, peptone, tryptone and maltose had been omitted, and with $\mathrm{H}_{2} / \mathrm{CO}_{2}(80: 20 ; 100 \mathrm{kPa})$ as the gas phase. Possible growth substrates were tested in the same medium in the presence of sulfur: substrates were added at a concentration of $500 \mathrm{mg} \mathrm{l}^{-1}$ and with $\mathrm{N}_{2}(100 \% ; 100 \mathrm{kPa})$ as the gas phase. Three further transfers were performed on each substrate that allowed growth. The influence of yeast extract on growth with substrates was tested by adding this compound to the basal medium at a concentration of $200 \mathrm{mg} \mathrm{l}^{-1}$.

Effects of electron acceptors on growth, glucose metabolism and hydrogen and oxygen susceptibility. Elemental sulfur $(1 \%)$, cystine $(1 \%)$, sulfate $(20 \mathrm{mM})$ and thiosulfate $(20 \mathrm{mM})$ were tested as potential electron acceptors in culture medium. The influence of elemental sulfur on growth and on the amounts of acetate and L-alanine produced during glucose fermentation was investigated according to the method of Ravot et al. (1996a, b). Amino acid concentrations were determined by liquid chromatography (Moore et al., 1958). The influence of hydrogen on growth was examined in medium supplemented with or without elemental sulfur under $\mathrm{H}_{2} / \mathrm{CO}_{2}(80: 20 ; 100 \mathrm{kPa})$ and under $\mathrm{N}_{2} / \mathrm{CO}_{2}(80: 20 ; 100 \mathrm{kPa})$. Susceptibility to oxygen was tested by incubating the organism in the culture medium at $55^{\circ} \mathrm{C}$ under aerated and microaerophilic conditions (L'Haridon et al., 1998).

Antibiotic susceptibility. The sensitivity of strains SL24 ${ }^{\mathrm{T}}$ and $\mathrm{SL} 25^{\mathrm{T}}$ to ampicillin, chloramphenicol, streptomycin, vancomycin and rifampicin (all from Sigma) at 10, 25, 50 and $100 \mu \mathrm{g} \mathrm{m}{ }^{-1}$ was tested at $55^{\circ} \mathrm{C}$.

Light and electron microscopy. An Olympus BX-60 microscope equipped with an Olympus OM-2 camera was used routinely for observation and to obtain photomicrographs. For negative staining, $20 \mu \mathrm{l}$ cell suspension, fixed with $2 \%$ $(\mathrm{w} / \mathrm{v})$ glutaraldehyde, was dropped on Formvar/carboncoated grids (400 mesh) and stained with $2 \%(\mathrm{w} / \mathrm{v})$ phosphotungstate. Thin sections were prepared as described previously (Bonch-Osmolovskaya et al., 1990). Electron micrographs were taken using a model JEM-100 electron microscope (JOEL).

$\mathrm{H}_{2} \mathrm{~S}$ production. $\mathrm{H}_{2} \mathrm{~S}$ production was evaluated by adding $500 \mu \mathrm{l}$ of a solution of $\mathrm{CuSO}_{4}(5 \mathrm{mM})$ and $\mathrm{HCl}(50 \mathrm{mM})$ to $250 \mu \mathrm{l}$ culture grown at $55^{\circ} \mathrm{C}$. The dark-brown precipitate demonstrating the presence of sulfide was compared with that of the uninoculated medium incubated under the same conditions. Sulfide was determined photometrically as colloidal CuS by using the method of Cord-Ruwisch (1985).

DNA extraction and base composition. The genomic DNA of strains was isolated by using the procedure described by Charbonnier \& Forterre (1994). The DNA was purified on a caesium chloride gradient (Sambrook et al., 1989) and purity was checked spectrophotometrically. The $\mathrm{G}+\mathrm{C}$ content of the DNA was determined from the melting point, according to Marmur \& Doty (1962), using Escherichia coli DNA 
(52 mol \% G $+\mathrm{C})$, Clostridium perfringens DNA (24 mol \% $\mathrm{G}+\mathrm{C})$ and Micrococcus luteus DNA $(73 \mathrm{~mol} \% \mathrm{G}+\mathrm{C})($ all from Sigma) as standards.

16S rDNA-based phylogenetic analysis. Extraction of genomic DNA, PCR-mediated amplification of the $16 \mathrm{~S}$ rDNA and sequencing of the purified PCR product were carried out according to Rainey et al. (1996). The sequence reaction mixtures were electrophoresed using a model 373A automatic sequencer (Applied Biosystems). The 16S rDNA sequences were aligned with published sequences of the DSMZ database using the ae 2 editor (Maidak et al., 1996) and sequences retrieved from EMBL. Evolutionary distances were calculated by the method of Jukes \& Cantor (1969). Distance-analysis dendrograms were reconstructed as described by De Soete (1983). Bootstrap analysis was used to evaluate the tree topology after neighbour joining by performing 500 resamplings (Felsenstein, 1985).

DNA-DNA hybridization experiments. Genetic relatedness was investigated by slot-blot DNA-DNA hybridization by using a random-prime labelling and signal-amplification system (Amersham Life Sciences) according to the procedure described by Kristjánsson et al. (1994). Increasing amounts of target DNA (50-100 ng) denatured in 0.4 M NaOH were blotted onto a nylon hybridization membrane (Bio-Rad) and probed with $200 \mathrm{ng}$ labelled tracer DNA. For each duplicate of DNA-DNA association $(15 \mathrm{~h}$ in $4 \times \mathrm{SSC}$ buffer with formamide, $0.5 \%$ blocking agent, $5 \%$ dextran sulfate, $100 \mu \mathrm{g}$ denatured sheared salmon-sperm DNA ml${ }^{-1}$ ), the temperature of hybridization chosen was in the optimal range for the hybridization buffer (Johnson, 1989; Ivanova et al., 1988). Final highly stringent washes and signal amplification were performed according to the manufacturer's instructions. Hybridization signals were detected with a Storm fluorescent scanner (Molecular Dynamics) and analysed by using the IMAGE-QUANT program. The signal (maximum peak area) produced by self-hybridization of the probe with homologous target DNA was set as $100 \%$ and was compared with the signal generated by heterologous DNA.

\section{RESULTS AND DISCUSSION}

\section{Enrichments and isolation}

Stratal fluids from different horizons of the Samotlor oilfield (1700-2500 $\mathrm{m}$ depth), having temperatures of 45 to $84^{\circ} \mathrm{C}$, were taken directly from production wellheads through a tapping fitted on the production line. Stratal waters had total mineral contents ranging from 5.7 to $32.9 \mathrm{~g}^{-1}$ and $\mathrm{pH}$ values ranging from 5.5 to 7.5 . Some sites of the Samotlor oilfield are exploited by flooding with a mixture of freshwater from the Vah River (about 30\%) and production water. The temperature of the injection water varied from 4 to $40{ }^{\circ} \mathrm{C}$ depending on the season. The salinity of the injection water varied from 9 to $17 \mathrm{~g} \mathrm{l}^{-1}$. Enrichments of thermophiles were performed by inoculating the collected production fluids into anaerobic enrichment medium and incubating at $58^{\circ} \mathrm{C}$. Within 4 days, turbidity due to cell growth was observed. This growth consisted of small, rod-shaped bacteria with a characteristic outer sheath-like structure, a feature typical of the Thermotogales. The sheathed bacteria were purified by streaking subcultures onto solidified medium and

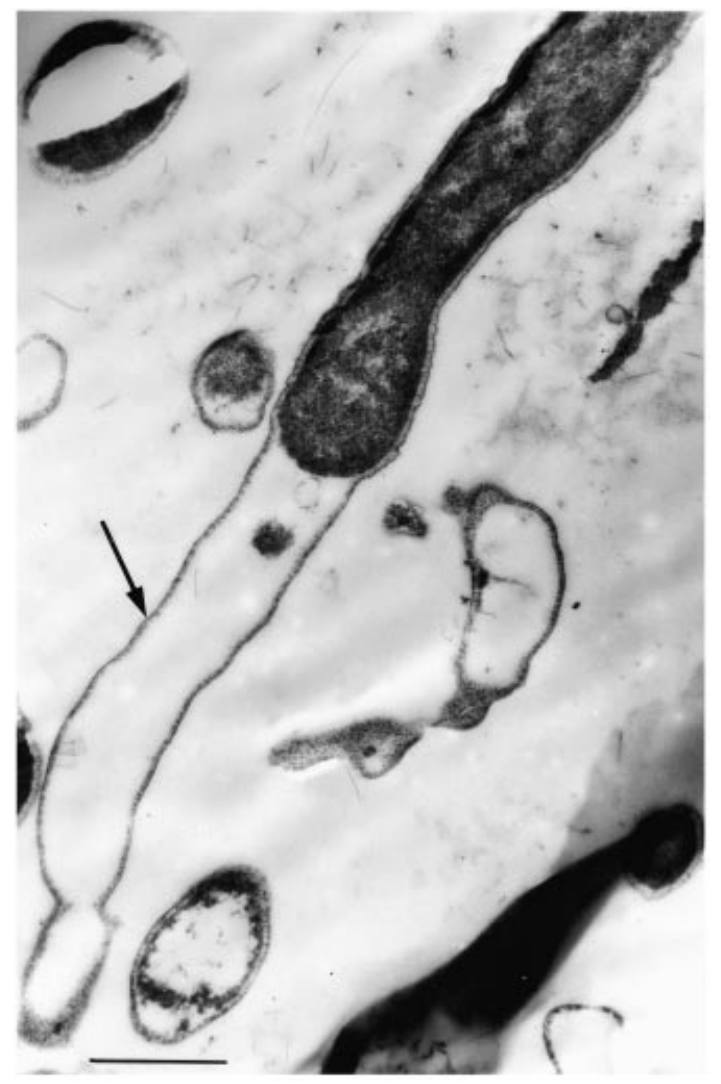

Fig. 1. Thin section of cells of strain $S L 24^{\top}$, showing the typical sheath-like structure (arrow). Bar, $500 \mathrm{~nm}$.

incubating them in an anaerobic jar at $55^{\circ} \mathrm{C}$. After 4 days, whitish, round colonies (1-2 $\mathrm{mm}$ in diameter) were obtained. Five single colonies were picked and the isolation procedure was repeated at least three times before each of the isolates, designated SL24, SL25, SL27, SL29 and SL32, was considered pure. Isolates SL24 ${ }^{\mathrm{T}}$ and SL25 ${ }^{\mathrm{T}}$ were studied in detail.

\section{Phenotypic characteristics of strains SL24 ${ }^{\top}$ and $\mathrm{SL}^{2} 5^{\top}$}

Cells of strains SL24 ${ }^{\mathrm{T}}$ and SL25 ${ }^{\mathrm{T}}$ were rod-shaped, about $0.9-2.5 \mu \mathrm{m}$ long and about $0.3-0.6 \mu \mathrm{m}$ wide. Each negatively stained unsheathed cell examined by transmission electron microscopy possessed a single polar flagellum (data not shown). During the growth phase, one or two cells per sheath were observed and the sheaths became longer. In the stationary growth phase, the cells became large spheres surrounded by the sheath. Thin sections of cells of strains SL24 ${ }^{\mathrm{T}}$ (Fig. 1) and SL25 ${ }^{\mathrm{T}}$ (data not shown) revealed the Gramnegative structure of the cell wall with outer membrane.

The two organisms had different temperature, $\mathrm{pH}$ and salinity ranges (Fig. 2). Details are given in the species descriptions below and in Table 1. Under optimal growth conditions (optimal temperature, $\mathrm{pH}$ and 

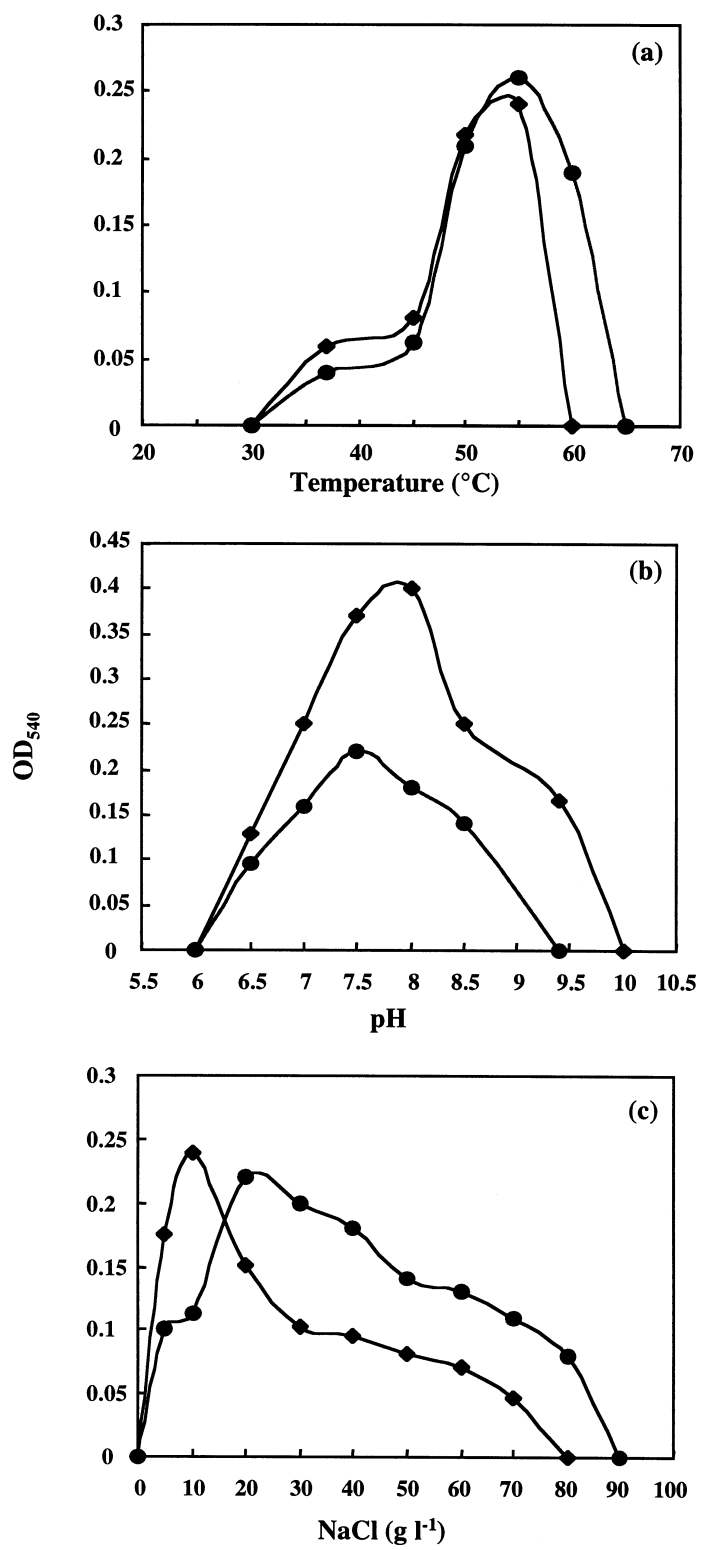

Fig. 2. Effects of temperature, $\mathrm{pH}$ and concentration of $\mathrm{NaCl}$ on growth of strains $\mathrm{SL}_{2} 4^{\top}(\mathbf{0})$ and $\mathrm{SL}_{2} 5^{\top}(\diamond)$. Final $\mathrm{OD}_{540}$ measured after $24-36 \mathrm{~h}$ incubation for strain $\mathrm{SL} 24^{\top}$ and after $36-48 \mathrm{~h}$ for strain $\mathrm{SL25}{ }^{\top}$ are plotted as a function of temperature (in the presence of $25 \mathrm{~g} \mathrm{NaCl}^{-1}$ at $\mathrm{pH}$ 8) (a), $\mathrm{pH}$ (at $55^{\circ} \mathrm{C}$ in the presence of $25 \mathrm{~g} \mathrm{NaCl} \mathrm{I}^{-1}$ ) (b) and $\mathrm{NaCl}$ concentration (at $55^{\circ} \mathrm{C}$ and $\mathrm{pH}$ 8) (c).

$\mathrm{NaCl}$ ), the doubling time of strain SL24 ${ }^{\mathrm{T}}$ was approximately 115 min.

Both strains were strictly anaerobic, organotrophic organisms. Their growth was prevented by the presence of low levels of oxygen $(0 \cdot 2-1 \%, v / v)$ and under the autotrophic culture conditions tested. In the absence of yeast extract, strain SL2 $4^{\mathrm{T}}$ was able to grow with pyruvate, peptone and a papaic digest of soybean meal. Its growth on pyruvate and peptone was stimulated by the addition of $0.02 \%(\mathrm{w} / \mathrm{v})$ yeast extract. In the presence of yeast extract, strain SL24 ${ }^{\mathrm{T}}$ was able to grow with a wide range of substrates, such as arabinose, xylose, cellobiose, dextrin, sucrose, glucose, fructose, maltose, ribose, trehalose, xylan, pyruvate, peptone and papaic digests of soybean meal and starch. Strain SL25 ${ }^{\mathrm{T}}$ was unable to grow in the absence of yeast extract. In the presence of yeast extract, growth was observed with sucrose, glucose, fructose, maltose, ribose, trehalose, xylan, pyruvate, peptone and a papaic digest of soybean meal and galactose. Casein, cellulose, formate, acetate, ethanol, methanol, mannitol, rhamnose, Casamino acids, casein, beef extract and an amino acid mixture did not support growth of either strain, even when combined with yeast extract $\left(200 \mathrm{mg} \mathrm{l}^{-1}\right)$.

Molecular hydrogen, acetate, lactate and alanine were the main metabolic products detected after glucose fermentation, irrespective of the presence of sulfur. In the absence of sulfur, small amounts of ethanol $(0.17 \mathrm{mM})$ were produced. In all cases, about $1 \mathrm{~mol}$ $\mathrm{CO}_{2}$ was produced per mol acetate produced.

Both strains were completely inhibited by $\mathrm{H}_{2}$ in the headspace [gas phase $\mathrm{H}_{2} / \mathrm{CO}_{2}(80: 20 ; 100 \mathrm{kPa})$ ]. Inhibition of growth by $\mathrm{H}_{2}$ was overcome by the addition of sulfur. The addition of sulfur resulted in the production of $\mathrm{H}_{2} \mathrm{~S}$ and a decrease in the cell yield. Sulfate, cystine and thiosulfate were unable to serve as alternative electron acceptors. The presence of sulfur as electron acceptor, lowering the hydrogen partial pressure of the medium, also had an effect on the alanine/acetate and alanine/glucose ratios produced during glucose fermentation by both strains. As an example, when $\mathrm{S}^{0}$ was absent, the alanine/acetate and alanine/glucose ratios were respectively about 0.6 and 0.5 after growth of strain SL24T. In the presence of $\mathrm{S}^{0}$, the two ratios decreased to respective values of 0.05 and 0.02 (data not shown).

Strain SL25 ${ }^{\mathrm{T}}$ was sensitive to chloramphenicol $(10 \mu \mathrm{g}$ $\left.\mathrm{ml}^{-1}\right)$, ampicillin $\left(10 \mu \mathrm{g} \mathrm{ml}^{-1}\right)$, vancomycin $(50 \mu \mathrm{g}$ $\left.\mathrm{ml}^{-1}\right)$, streptomycin $\left(100 \mu \mathrm{g} \mathrm{ml}^{-1}\right)$ and rifampicin $\left(100 \mu \mathrm{g} \mathrm{ml}^{-1}\right)$. Strain SL24 ${ }^{\mathrm{T}}$ was resistant to the antibiotics tested at $100 \mu \mathrm{g} \mathrm{ml}^{-1}$.

\section{S rDNA sequence analysis}

16S rDNA sequence analysis based on 899 nucleotides placed strains SL24 and SL2 $25^{\mathrm{T}}$ as close relatives of $P$. miotherma $42-6^{\mathrm{T}}(99 \cdot 4$ and $98.9 \%$ similarity) and $P$. mobilis DSM $10674^{\mathrm{T}}$ (98.5 and $97.9 \%$ similarity). Lower similarities were obtained with isolates vp56 and vp424 isolated from oil reservoirs in California (Orphan et al., 2000) (respectively 97.9 and 97.3\% similarity between vp56 and strains SL24 ${ }^{\mathrm{T}}$ and SL25 ${ }^{\mathrm{T}}$ and 97.2 and $96.8 \%$ between vp424 and SL24 ${ }^{\mathrm{T}}$ and $\mathrm{SL} 25^{\mathrm{T}}$ ). Members of other genera of the Thermotogaceae showed lower similarity. Phylogenetic trees generated using distance algorithms and maximumlikelihood analysis gave the same topology. Bootstrap values from 500 samplings confirmed the affiliation of 


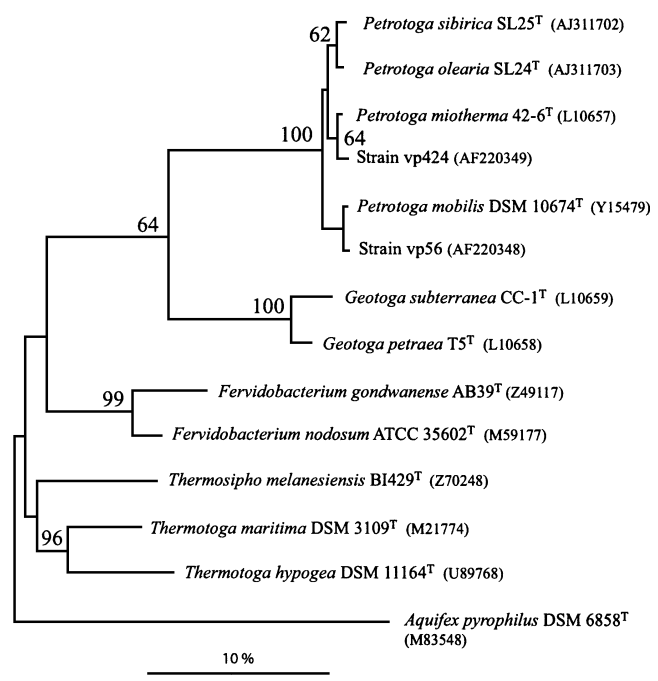

Fig. 3. $16 \mathrm{~S}$ rDNA sequence-based phylogenetic distance-analysis dendrogram showing the phylogenetic positions of strains $\mathrm{SL} 24^{\top}$ and $\mathrm{SL} 25^{\top}$ and related species in the genus Petrotoga and other members of the order Thermotogales. The sequence of Aquifex pyrophilus served as an outgroup. A mask was set to include only those positions that were occupied in each of the 14 sequences. Bar, 10 inferred nucleotide substitutions per 100 nucleotides. Numbers at branching points refer to bootstrap values $(>70 \%)$.

both strains to a clade (monophyletic taxon) that also included P. miotherma $42-6^{\mathrm{T}}$ and P. mobilis $\mathrm{SJ} 95^{\mathrm{T}}$ (Fig. $3)$. On the basis of partial 16S rDNA sequences (500 nucleotides), strains SL25 ${ }^{\mathrm{T}}$, SL27, SL29 and SL32 were identical.

\section{DNA base composition and DNA-DNA hybridization}

The $\mathrm{G}+\mathrm{C}$ contents of the DNA of isolates SL2 $4^{\mathrm{T}}$ and SL $25^{\mathrm{T}}$ were respectively 35.0 and $33.0 \mathrm{~mol} \%$, as determined by the thermal denaturation method. Low relatedness was obtained between bulk cellular DNAs of the two isolates and that from P. miotherma $42-6^{\mathrm{T}}$. Strain SL24 ${ }^{\mathrm{T}}$ exhibited hybridization values $\leqslant 11 \%$ with $P$. miotherma and $32 \%$ with strain SL25 $5^{\mathrm{T}}$. The hybridization value between strain $\mathrm{SL}^{2} 5^{\mathrm{T}}$ and $P$. miotherma was $\leqslant 20 \%$.

\section{Taxonomic position}

When a number of different taxonomic parameters are compared, several phenotypic differences are apparent that can be used to differentiate strains SL24 ${ }^{\mathrm{T}}$ and SL $25^{\mathrm{T}}$ from the two Petrotoga species described. The novel isolates differ from them in their cell size, flagellation, maximum temperature and optimum $\mathrm{pH}$ for growth and inability to reduce thiosulfate (Table 1). In contrast to P. mobilis, strains SL $24^{\mathrm{T}}$ and SL $25^{\mathrm{T}}$ grow optimally at moderate $\mathrm{NaCl}$ concentrations and are resistant to low concentrations of antibiotics. They differ from their closest phylogenetic relative, $P$. miotherma, by their motility, their inability to form spherical bodies and their ability to grow on xylan. Moreover, the levels of genetic relationship between the two strains and $P$. miotherma, determined by DNA-DNA hybridization, indicate that these organisms cannot be assigned to this species (Johnson, 1989). Similarly, low levels of DNA-DNA hybridization were measured between strains SL24 ${ }^{\mathrm{T}}$ and SL25 ${ }^{\mathrm{T}}$. Although the two strains share similar phenotypic

Table 1. Differentiating characteristics between strains $S L 24^{\top}$ and $S L 25^{\top}, P$. miotherma and P. mobilis

Data for reference species were taken from Davey et al. (1993) (P. miotherma) and Lien et al. (1998) (P. miotherma and $P$. mobilis). ND, Not determined.

\begin{tabular}{|c|c|c|c|c|}
\hline Characteristic & P. miotherma & P. mobilis & $\mathrm{SL24}^{\mathrm{T}}$ & $\mathrm{SL25}^{\mathrm{T}}$ \\
\hline Cell size $(\mu \mathrm{m})$ & $0.6 \times 2.0-7 \cdot 5$ & $0 \cdot 5-1 \cdot 5 \times 1-50 \cdot 0$ & $0 \cdot 3-0 \cdot 6 \times 0 \cdot 9-2 \cdot 5$ & $0 \cdot 3-0 \cdot 6 \times 0 \cdot 9-2 \cdot 5$ \\
\hline No. of cells per sheath & $1-5$ & $1-24$ & $1-2$ & $1-2$ \\
\hline Motility & - & + & + & + \\
\hline Flagellation/no. flagella & - & Subpolar/some & Polar/1 & Polar/1 \\
\hline Formation of spherical bodies & + & - & + & + \\
\hline Temperature range $\left({ }^{\circ} \mathrm{C}\right)$ [opt.] & $35-65[55]$ & $40-65[58-60]$ & $37-60[55]$ & $37-55[55]$ \\
\hline pH range [opt.] & $5 \cdot 5-9 \cdot 0[6 \cdot 5]$ & $5 \cdot 5-8 \cdot 5[6 \cdot 5-7 \cdot 0]$ & $6 \cdot 5-8 \cdot 5[7 \cdot 5]$ & $6 \cdot 5-9 \cdot 4[8 \cdot 0]$ \\
\hline $\mathrm{NaCl}$ range (\%) [opt.] & $0 \cdot 5-10 \cdot 0[2 \cdot 0]$ & $0 \cdot 5-9 \cdot 0[3-4]$ & $0 \cdot 5-8 \cdot 0[2 \cdot 0]$ & $0 \cdot 5-7 \cdot 0[1 \cdot 0]$ \\
\hline $\mathrm{G}+\mathrm{C}$ content $(\mathrm{mol} \%)$ & $32, * 34 \cdot 2,40$ & $31, * 34$ & $35^{*}$ & $33 *$ \\
\hline Reduction of thiosulfate & + & + & - & - \\
\hline \multicolumn{5}{|l|}{ Substrates utilized: } \\
\hline Xylan & - & + & + & + \\
\hline Galactose & + & + & - & + \\
\hline Xylose & + & + & + & - \\
\hline Arabinose & + & + & + & - \\
\hline Cellobiose & ND & + & + & - \\
\hline
\end{tabular}

*Values obtained by the thermal denaturation method. Other values were obtained by the HPLC method. 
characteristics, they differ in their temperature, $\mathrm{pH}$ and $\mathrm{NaCl}$ ranges and optima for growth and in the spectrum of substrates that they are able to oxidize. On the basis of these distinctive phenotypic, phylogenetic and genomic features, strains SL $24^{\mathrm{T}}$ and SL2 $25^{\mathrm{T}}$ should be considered as novel species of the genus Petrotoga, for which we propose the names Petrotoga olearia sp. nov. and Petrotoga sibirica sp. nov., respectively.

\section{Description of Petrotoga olearia sp. nov.}

Petrotoga olearia (o.le.a'ri.a. L. fem. adj. olearia pertaining to oil, referring to its site of isolation).

Cells are Gram-negative rods, about $0 \cdot 9-2 \cdot 5 \mu \mathrm{m}$ long and about $0 \cdot 3-0.6 \mu \mathrm{m}$ wide. They are motile by means of a polar flagellum. A sheath-like structure is clearly visible. Cells occur singly, in pairs or in chains containing a maximum of six cells. In the stationary growth phase, the cells became large spheres surrounded by the sheath. When cultivated on Gelrite plates containing peptone, tryptone, yeast extract and maltose, white colonies are formed, about $1-2 \mathrm{~mm}$ in diameter. Growth occurs at temperatures between 37 and $60^{\circ} \mathrm{C}$, with an optimum at $55^{\circ} \mathrm{C}$. Growth occurs at $\mathrm{pH}$ values between 6.5 and 8.5 , with an optimum at approximately $7 \cdot 5$, and at $\mathrm{NaCl}$ concentrations between 0.5 and $8 \%$, with an optimum at $2 \%$. Strictly anaerobic. $\mathrm{H}_{2}$ inhibits growth, but this is alleviated by the addition of elemental sulfur. Under these conditions, hydrogen sulfide is produced. Thiosulfate, cystine and sulfate cannot be used as electron acceptors. Metabolism shifts to alanine production in the absence of elemental sulfur. Pyruvate, peptone and papaic digest of soybean meal support growth in the absence of yeast extract. In the presence of yeast extract, a variety of organic compounds are used, including xylose, arabinose and cellobiose. Growth is observed in the presence of ampicillin, chloramphenicol, streptomycin, vancomycin and rifampicin at final concentrations of $100 \mu \mathrm{g} \mathrm{ml}^{-1}$. The DNA base composition of the type strain is $35 \mathrm{~mol} \% \mathrm{G}+\mathrm{C}$ (as determined by the thermal denaturation method). Phylogenetic analysis based on the almost complete 16 rRNA sequence conclusively affiliates the strain with the Thermotogales and, more specifically, with the genus Petrotoga. Low DNA similarity to $P$. miotherma and $P$. sibirica.

The type strain is strain SL24 ${ }^{\mathrm{T}}$ (= DSM $13574^{\mathrm{T}}=$ JCM $11234^{\mathrm{T}}$ ), which was obtained from an oil/water mixture collected from a deep, continental oil reservoir in Western Siberia (Russia).

\section{Description of Petrotoga sibirica sp. nov.}

Petrotoga sibirica (si.bi'ri.ca. N.L. fem. adj. sibirica originating from Siberia, referring to its site of isolation).

Cells are Gram-negative rods, about $0 \cdot 9-2 \cdot 5 \mu \mathrm{m}$ long and about $0.3-0.6 \mu \mathrm{m}$ wide. They are motile by means of a polar flagellum. A sheath-like structure is clearly visible. Cells occur singly, in pairs or in chains containing a maximum of six cells. In the stationary growth phase, the cells became large spheres surrounded by the sheath. When cultivated on Gelrite plates containing peptone, tryptone, yeast extract and maltose, white colonies are formed, about $1-2 \mathrm{~mm}$ in diameter. Growth occurs at temperatures between 37 and $55^{\circ} \mathrm{C}$, with an optimum at $55^{\circ} \mathrm{C}$. Growth occurs at $\mathrm{pH}$ values between 6.5 and 9.4 , with an optimum of approximately 8 , and at $\mathrm{NaCl}$ concentrations between 0.5 and $7 \%$, with an optimum at $1 \%$. Strictly anaerobic. $\mathrm{H}_{2}$ inhibits growth, but this is alleviated by the addition of elemental sulfur. Under these conditions, hydrogen sulfide is produced. Thiosulfate, cystine and sulfate cannot be used as electron acceptors. Metabolism shifts to alanine production in the absence of elemental sulfur. Yeast extract is required for growth. In the presence of yeast extract, a variety of compounds are used, but some, such as xylose, arabinose and cellobiose, are not. Growth is inhibited in the presence of ampicillin and chloramphenicol $\left(10 \mu \mathrm{g} \mathrm{ml}^{-1}\right)$, vancomycin $\left(50 \mu \mathrm{g} \mathrm{ml}^{-1}\right)$, streptomycin and rifampicin (each $100 \mu \mathrm{g} \mathrm{ml}^{-1}$ ). The DNA base composition of the type strain is $33 \mathrm{~mol} \% \mathrm{G}+\mathrm{C}$ (as determined by the thermal denaturation method). Phylogenetic analysis based on the almost complete 16 rRNA sequence conclusively affiliates the strain with the Thermotogales and, more specifically, with the genus Petrotoga. Low DNA similarity is found to $P$. miotherma and P. olearia.

The type strain is strain SL25 $5^{\mathrm{T}}\left(=\mathrm{DSM} 13575^{\mathrm{T}}=\right.$ JCM $11235^{\mathrm{T}}$ ), which was obtained from an oil/water mixture collected from a deep, continental oil reservoir in Western Siberia (Russia).

\section{ACKNOWLEDGEMENTS}

We thank Tamara Nazina, Nikolai Chernyh and the Russian Samotlor oil company for sample collection. This work was supported by Intas (project 96-1341).

\section{REFERENCES}

Andrews, K. T. \& Patel, B. K. C. (1996). Fervidobacterium gondwanense sp. nov., a new thermophilic anaerobic bacterium isolated from nonvolcanically heated geothermal waters of the Great Artesian Basin of Australia. Int J Syst Bacteriol 46, 265-269.

Antoine, E., Cilia, V., Meunier, J. R., Guezennec, J., Lesongeur, F. \& Barbier, G. (1997). Thermosipho melanesiensis sp. nov., a new thermophilic anaerobic bacterium belonging to the order Thermotogales, isolated from deep-sea hydrothermal vents in the southwestern Pacific Ocean. Int J Syst Bacteriol 47, 1118-1123.

Balch, W. E. \& Wolfe, R. S. (1976). New approach to the cultivation of methanogenic bacteria: 2-mercaptoethanesulfonic acid (HS-CoM)dependent growth of Methanobacterium ruminantium in a pressurized atmosphere. Appl Environ Microbiol 32, 781-791.

Bonch-Osmolovskaya, E. A., Sokolova, T. G., Kostrikina, N. A. \& Zavarzin, G. A. (1990). Desulfurella acetivorans gen. nov. and sp. nov. - a new thermophilic sulfur-reducing eubacterium. Arch Microbiol 153, 151-155.

Charbonnier, F. \& Forterre, P. (1994). Comparison of plasmid DNA topology among mesophilic and thermophilic eubacteria and archaebacteria. J Bacteriol 176, 1251-1259. 
Cord-Ruwisch, R. (1985). A quick method for the determination of dissolved and precipitated sulfides in cultures of sulfate-reducing bacteria. J Microbiol Methods 4, 33-36.

Davey, M. E., Wood, W. A., Key, R., Nakamura, K. \& Stahl, D. A. (1993). Isolation of three species of Geotoga and Petrotoga: two new genera, representing a new lineage in the bacterial line of descent distantly related to the "Thermotogales". Syst Appl Microbiol 16, 191-200.

De Soete, G. (1983). A least squares algorithm for fitting additive trees to proximity data. Psychometrika 48, 621-626.

Fardeau, M.-L., Ollivier, B., Patel, B. K. C., Magot, M., Thomas, P., Rimbault, A., Rocchiccioli, F. \& Garcia, J.-L. (1997). Thermotoga hypogea sp. nov., a xylanolytic, thermophilic bacterium from an oilproducing well. Int J Syst Bacteriol 47, 1013-1019.

Felsenstein, J. (1985). Confidence limits on phylogenies: an approach using the bootstrap. Evolution 39, 783-791.

Grassia, G. S., McLean, K. M., Glénat, P., Bauld, J. \& Sheehy, A. J. (1996). A systematic survey for thermophilic fermentative bacteria and archaea in high temperature petroleum reservoirs. FEMS Microbiol Ecol 21, 47-58.

Huber, R., Langworthy, T. A., König, H., Thomm, M., Woese, C. R., Sleytr, U. B. \& Stetter, K. O. (1986). Thermotoga maritima sp. nov. represents a new genus of unique extremely thermophilic eubacteria growing up to $90^{\circ} \mathrm{C}$. Arch Microbiol 144, 324-333.

Huber, R., Woese, C. R., Langworthy, T. A., Fricke, H. \& Stetter, K. O. (1989). Thermosipho africanus gen. nov., represents a new genus of thermophilic eubacteria within the "Thermotogales". Syst Appl Microbiol 12, 32-37.

Huber, R., Woese, C. R., Langworthy, T. A., Kristjansson, J. K. \& Stetter, K. O. (1990). Fervidobacterium islandicum sp. nov., a new extremely thermophilic eubacterium belonging to the "Thermotogales". Arch Microbiol 154, 105-111.

Ivanova, T. L., Turova, T. P. \& Antonov, A. S. (1988). DNA-DNA hybridization studies on some purple non sulfur bacteria. Syst Appl Microbiol 10, 259-263.

Jannasch, H. W., Huber, R., Belkin, S. \& Stetter, K. O. (1988). Thermotoga neapolitana sp. nov. of the extremely thermophilic, eubacterial genus Thermotoga. Arch Microbiol 150, 103-104.

Jeanthon, C., Reysenbach, A.-L., L'Haridon, S., Gambacorta, A., Pace, N. R., Glénat, P. \& Prieur, D. (1995). Thermotoga subterranea sp. nov., a new thermophilic bacterium isolated from a continental oil reservoir. Arch Microbiol 164, 91-97.

Jeanthon, C., Bulygina, E. A., Chernyh, N. A. \& 12 other authors (2000). Cultural and molecular diversity of microbial communities from a high temperature petroleum reservoir in Western Siberia. International Congress for Extremophiles 2000, 3-7 September 2000, Hamburg-Harburg, Germany. Abstract.

Johnson, J. L. (1989). Nucleic acids in bacterial classification. In Bergey's Manual of Systematic Bacteriology, vol. 4, pp. 2306-2309. Edited by S. T. Williams, M. E. Sharpe \& J. G. Holt. Baltimore: Williams \& Wilkins.

Jukes, T. H. \& Cantor, C. R. (1969). Evolution of protein molecules. In Mammalian Protein Metabolism, pp. 21-132. Edited by H. N. Munro. New York: Academic Press.

Kevbrin, V. V. \& Zavarzin, G. A. (1992). The influence of sulfur compounds on the growth of halophilic homoacetic bacterium Acetohalobium arabaticum. Microbiology (English translation of Mikrobiologiya) 61, 812-817.

Koch, R., Canganella, F., Hippe, H., Jahnke, K. D. \& Antranikian, G. (1997). Purification and properties of a thermostable pullulanase from a newly isolated thermophilic anaerobic bacterium, Fervidobacterium pennavorans Ven5. Appl Environ Microbiol 63, 1088-1094.

Kristjánsson, J. K., Hjörleifsdóttir, S., Marteinsson, V. T. \& Alfredsson, G. A. (1994). Thermus scotoductus, sp. nov., a pigment-producing thermophilic bacterium from hot tap water in Iceland and including Thermus sp. X-1. Syst Appl Microbiol 17, 44-50.

L'Haridon, S., Cilia, V., Messner, P., Raguénès, G., Gambacorta, A., Sleytr, U. B., Prieur, D. \& Jeanthon, C. (1998). Desulfurobacterium thermolithotrophum gen. nov., sp. nov., a novel autotrophic, sulfurreducing bacterium isolated from a deep-sea hydrothermal vent. Int $J$ Syst Bacteriol 48, 701-711.

L'Haridon, S., Miroshnichenko, M. L., Hippe, H., Fardeau, M.-L., Bonch-Osmolovskaya, E., Stackebrandt, E. \& Jeanthon, C. (2001). Thermosipho geolei sp. nov., a thermophilic bacterium isolated from a continental petroleum reservoir in Western Siberia. Int J Syst Evol Microbiol 51, 1327-1334.

Lien, T., Madsen, M., Rainey, F. A. \& Birkeland, N.-K. (1998). Petrotoga mobilis sp. nov., from a North Sea oil-production well. Int $J$ Syst Bacteriol 48, 1007-1013.

Maidak, B. L., Olsen, G. J., Larsen, N., Overbeek, R., McCaughey, M. J. \& Woese, C. R. (1996). The Ribosomal Database Project (RDP). Nucleic Acids Res 24, 82-85.

Marmur, J. \& Doty, D. (1962). Determination of the base composition of deoxyribonucleic acid from its thermal denaturation temperature. J Mol Biol 5, 109-118.

Miroshnichenko, M. L., Hippe, H., Stackebrandt, E., Kostrikina, N. A., Chernyh, N. A., Jeanthon, C., Nazina, T. N., Belyaev, S. S. \& Bonch-Osmolovskaya, E. A. (2001). Isolation and characterization of Thermococcus sibiricus sp. nov. from a Western Siberia high-temperature oil reservoir. Extremophiles 5, 85-91.

Moore, S., Spackman, D. H. \& Stein, W. H. (1958). Chromatography of amino acids on sulfonated polystyrene resins: an improved system. Anal Chem 30, 1158-1190.

Nazina, T. N., Tourova, T. P., Poltaraus, A. B. \& 8 other authors (2001). Taxonomic study of aerobic thermophilic bacilli: descriptions of Geobacillus subterraneus gen. nov., sp. nov. and Geobacillus uzenensis sp. nov. from petroleum reservoirs and transfer of Bacillus stearothermophilus, Bacillus thermocatenulatus, Bacillus thermoleovorans, Bacillus kaustophilus, Bacillus thermoglucosidasius and Bacillus thermodenitrificans to Geobacillus as the new combinations G. stearothermophilus, G. thermocatenulatus, G. thermoleovorans, G. kaustophilus, G. thermoglucosidasius and G. thermodenitrificans. Int J Syst Evol Microbiol 51, 433-446.

Orphan, V. J., Taylor, L. T., Hafenbradl, D. \& Delong, E. F. (2000). Culture-dependent and culture-independent characterization of microbial assemblages associated with high-temperature petroleum reservoirs. Appl Environ Microbiol 66, 700-711.

Patel, B. K. C., Morgan, H. W. \& Daniel, R. M. (1985). Fervidobacterium nodosum gen. nov. and spec. nov., a new chemoorganotrophic, caldoactive, anaerobic bacterium. Arch Microbiol 141, 63-69.

Rainey, F. A., Ward-Rainey, N., Kroppenstedt, R. M. \& Stackebrandt, E. (1996). The genus Nocardiopsis represents a phylogenetically coherent taxon and a distinct actinomycete lineage: proposal of Nocardiopsaceae fam. nov. Int J Syst Bacteriol 46, 1088-1092.

Ravot, G., Magot, M., Fardeau, M.-L., Patel, B. K. C., Prensier, G., Egan, A., Garcia, J.-L. \& Ollivier, B. (1995). Thermotoga elfi sp. nov., a novel thermophilic bacterium from an African oil-producing well. Int J Syst Bacteriol 45, 308-314.

Ravot, G., Ollivier, B., Patel, B. K. C., Magot, M. \& Garcia, J.-L. (1996a). Emended description of Thermosipho africanus as a carbohydrate-fermenting species using thiosulfate as an electron acceptor. Int $J$ Syst Bacteriol 46, 321-323.

Ravot, G., Ollivier, B., Fardeau, M.-L., Patel, B. K. C., Andrews, K. T., Magot, M. \& Garcia, J.-L. (1996b). L-Alanine production from glucose fermentation by hyperthermophilic members of the domains Bacteria and Archaea: a remnant of an ancestral metabolism? Appl Environ Microbiol 62, 2657-2659.

Sambrook, J., Fritsch, E. F. \& Maniatis, T. (1989). Molecular Cloning: a Laboratory Manual, 2nd edn. Cold Spring Harbor, NY: Cold Spring Harbor Laboratory.

Slobodkin, A. I., Jeanthon, C., L'Haridon, S., Nazina, T., Miroshnichenko, M. \& Bonch-Osmolovskaya, E. (1999). Dissimilatory reduction of $\mathrm{Fe}(\mathrm{III})$ by thermophilic bacteria and archaea in deepsubsurface petroleum reservoirs of Western Siberia. Curr Microbiol 39, 99-102.

Stetter, K. O., Huber, R., Blöchl, E., Kurr, M., Eden, R. D., Fielder, M., Cash, H. \& Vance, I. (1993). Hyperthermophilic archaea are 
thriving in deep North Sea and Alaskan oil reservoirs. Nature 365, 743-745.

Takahata, Y., Nishijima, M., Hoaki, T. \& Maruyama, T. (2000). Distribution and physiological characteristics of hyperthermophiles in the Kubiki oil reservoir in Niigata, Japan. Appl Environ Microbiol 66, 73-79.

Takai, K. \& Horikoshi, K. (2000). Thermosipho japonicus sp. nov., an extremely thermophilic bacterium isolated from a deep-sea hydrothermal vent in Japan. Extremophiles 4, 9-17.

Wery, N., Lesongeur, F., Pignet, P., Derennes, V., Cambon-
Bonavita, M.-A., Godfroy, A. \& Barbier, G. (2001). Marinitoga camini gen. nov., sp. nov., a rod-shaped bacterium belonging to the order Thermotogales, isolated from a deep-sea hydrothermal vent. Int $J$ Syst Evol Microbiol 51, 495-504.

Windberger, E., Huber, R., Trincone, A., Fricke, H. \& Stetter, K. O. (1989). Thermotoga thermarum sp. nov. and Thermotoga neapolitana occurring in African continental solfataric springs. Arch Microbiol 151, 506-512.

Wolin, E. A., Wolin, M. J. \& Wolfe, R. S. (1963). Formation of methane by bacterial extracts. $J$ Biol Chem 238, 2882-2888. 